\title{
KRIMINALISASI PENGELOLAAN ZAKAT (TINJAUAN \\ KETENTUAN PASAL 41 UU NO 23 TAHUN 2011)
}

\author{
Niken Subekti Budi Utami \\ Destri Budi Nugraheni \\ Fakultas Hukum Universitas Gadjahmada \\ niken.subekti@mail.ugm.ac.id
}

\begin{abstract}
This research was conducted wih library research to obtain secondary data and field research to obtain primary data.

The results of this study indicate that in the view of Islamic Scientist, Zakat Management Act there are some drawbacks. First, under the coordination of placement BAZNAS, LAZ cause has no authority, but on the other side of the $L A Z$ are required to make the report public accounting. Second, $L A Z$ could only have authority when a public organization that has a community empowerment program, but this provision may result in unfair $L A Z$ in the management of zakat, as it will further the interests of these organizations. Third, to implement the Zakat Management Act needs to be made government regulation, so that its implementation will bring benefits to the community and not cause harm. According to the criminal scientist, the provisions of article 41 UUPZ which impose criminal sanctions for unlicensed LAZ that felt quite right, because the intent of legislator of UUPZ, zakat management is done professionally so that it will create a prosperous society, as well as the criteria of the criminalization of the LAZ is not permitted, which include the purpose of imposition of penalty, the onset of the victim, the principle of cost and the results, the ability of law enforcement officials and the public support, are not appropriate.
\end{abstract}

Keyword : zakat, LAZ,criminalitation

\begin{abstract}
Abstrak
Penelitian ini bertujuan untuk mengetahui pengelolaan zakat yang dilakukan oleh lembaga pengelola zakat apabila ditinjau dari perspektif Hukum Islam dan untuk mengetahui kriminalisasi dalam Pasal 41 UU No. 23 Tahun 2011 tentang Pengelolaan Zakat ditinjau dari perspektif Hukum Pidana. Penelitian ini adalah penelitian yuridis empiris yang dilakukan melalui penelitian pustaka dan penelitian lapangan dengan metode Focus Group Discussion. Narasumber adalah para ahli hukum Islam dan Hukum Pidana, sedangkan para responden adalah pengelola Lembaga Amil Zakat yang berada di Daerah Istimewa Yogyakarta, baik pengelola dari Lembaga Amil Zakat yang telah berijin maupun yang belum berijin. Hasil penelitian menunjukkan bahwa ahli hukum Islam menyatakan bahwa para ulama sepakat, wajib atas penguasa untuk mengangkat amil atau lembaga pengelola zakat. Namun, rumusan pengelolaan zakat secara sentralisasi berada di tangan pemerintah, masih dapat diperdebatkan dengan melihat peran masyarakat yang gemilang dalam pengelolaan zakat melalui LAZ. Kriteria kriminalisasi yang meliputi pemidanaan harus memperhatikan tujuannya, adanya unsur victimizing, prinsip biaya dan hasil, dan dukungan masyarakat, tidak terpenuhi dalam mengkriminalisasi LAZ seperti yang ditentukan dalam Pasal 41 UU Pengelolaan Zakat. Maksud dari pemerintah membentuk UUPZ baru, adalah untuk lebih meningkatkan pengumpulan, pendistribusian dan pendayagunaan zakat, sehingga dapat menciptakan masyarakat Indonesia yang sejahtera. Mencermati maksud tersebut, dirasakan kurang tepat ketentuan pemidanaan bagi LAZ karena tidak adanya catatan buruk kinerja LAZ dan apabila hukum dipandang sebagai alat untuk melakukan perubahan sosial, yaitu mengubah masyarakat yang miskin menjadi sejahtera, maka selayaknya bukan pendekatan sanksi yang dilakukan melainkan dengan pendekatan berupa insentif.
\end{abstract}

Kata kunci : Zakat, Lembaga Amil Zakat, kriminalisasi

\section{A. Pendahuluan}

Zakat merupakan salah satu Rukun Islam yang berupa kewajiban pembayaran sejumlah harta tertentu yang diwajibkan oleh Allah SWT, diberikan kepada orang yang berhak menerimanya (mustahiq) dengan syarat-syarat tertentu (Muhammmad Daud
Ali, 1998: 39). Zakat merupakan ibadah ruhiyah dan sosial, karena tujuan zakat selain untuk menyucikan harta juga sebagai wahana untuk menyejahterakan umat, yang akan dilelola lembaga khusus yaitu 'amil zakat, yakni orang atau badan hukum yang ditunjuk untuk bekerja secara 
profesional agar pengumpulan dan penyaluran zakat dapat berjalan secara tepat dan maksimal kepada 8 asnaf (orang yang berhak menerima).

Allah berfirman dalam QS. al-Taubah [9]:103 "Ambillah zakat dari sebagian harta mereka, dengan zakat itu kamu membersihkan dan menyucikan mereka dan berdoalah untuk mereka. Sesungguhnya doa kamu itu (menjadi) ketentraman jiwa bagi mereka. Allah Maha Mendengar lagi Maha Mengetahui." Kata "ambillah" dalam ayat tersebut mengandung pengertian "perintah" untuk memungut zakat secara sistematis dan profesional, yang ditujukan kepada ulil amri atau penguasa. Para ulama telah sepakat bahwa wajib atas penguasa untuk mengangkat para petugas zakat, seperti yang dilakukan oleh Nabi Muhammad dan KhalifahKhalifah sesudah beliau pada masa pemerintahannya masing-masing telah berbuat hal tersebut, yaitu mengangkat petugas zakat untuk mengurusi zakat (M. Yusuf Qardhawi, 1982 : 140).

Pemerintah dengan mendasarkan pada ketentuan Pasal 29 ayat 2 UUD 1945 serta mempertimbangkan bahwa zakat adalah kewajiban umat Islam mewujudkan keadilan sosial bagi seluruh rakyat, pada tanggal 23 September 1999, telah mengeluarkan UU terkait pengelolaan zakat yaitu UU No. 38 Tahun 1999 tentang Pengelolaan Zakat. UU tersebut menekankan pada aspek pengelolaan zakat, yakni kegiatan perencanaan, pengorganisasian, pelaksanaan, dan pengawasan terhadap pengumpulan dan pendistribusian serta pendayagunaan zakat.

Melalui UU 38 Tahun 1999 pemerintah menegaskan bahwa pengelola zakat adalah Badan Amil Zakat (BAZ) yang diprakarsai pendiriannya oleh pemerintah dan Lembaga Amil Zakat (LAZ) yang dikelola oleh masyarakat. BAZ yang mewakili pemerintah dan LAZ yang mewakili masyarakat mempunyai kedudukan yang sama atau sejajar ( Prasetyo, http://www.dsniamanah.or.id). Pada perkembangan selanjutnya LAZ tumbuh dan berkembang di masyarakat demikian pesat dan dapat mengumpulkan dana zakat, infak dan shadaqah yang lebih tinggi dibandingkan BAZ.

Sistem pengelolaan yang terpisah dan berjalan sendiri-sendiri antara BAZ dan LAZ, management yang lemah, penanganan yang kurang professional, serta kurang jelasnya mendistribusian zakat, sehingga zakat belum berdayaguna bagi masyarakat Indonesia, mendorong DPR kemudian mensahkan UU pengelolaan zakat yang baru, yaitu UU No. 23 Tahun 2011 dan mencabut UU No. 38 tahun 1999. UU No. 23 Tahun 2011 mengamanahkan pengelolaan zakat secara terintegrasi, dengan memberikan kewenangan kepada BAZNAS (Badan Amil Zakat Nasional) sebagai lembaga pengelola zakat milik pemerintah yang menjalankan pengelolaan zakat secara nasional. BAZNAS berfungsi sebagai perencana, pelaksana, pengendalian pengumpulan, pendistribusian dan pendayagunaan, hingga pelaporan zakat. Dengan demikian, lembaga-lembaga pengelola zakat yang selama ini dikelola oleh masyarakat, akan dikoordinasi oleh BAZNAS (http:/ /www.baznas.or.id).

Dalam UU 23 Tahun 2011 (selanjutnya disebut UUPZ) terdapat beberapa ketentuan pidana. Adanya sanksi yang diberikan kepada setiap pengelola zakat yang karena kelalaiannya tidak mencatat atau mencatat dengan tidak benar harta zakat, infaq, shadaqah, hibah, wasiat, waris, dan kafarat, yaitu diancam dengan hukuman kurungan selamalamanya tiga bulan dan/atau denda sebanyakbanyaknya Rp 30.000.000,00, yang juga terdapat dalam Undang-Undang Zakat lama (Pasal 21 UU No 38 Tahun 1999). Kemudian dalam Pasal 41 yang menyebutkan "setiap orang yang dengan sengaja dan melawan hukum melanggar ketentuan sesebagaimana dimaksud dalam Pasal 38 dipidana dengan pidana kurungan paling lama 1 (satu) tahun dan/atau pidana denda paling banyak $\mathrm{Rp}$ 50.000.000,00 (lima puluh juta rupiah)" Pasal 38 sendiri menyebutkan bahwa setiap orang dilarang dengan sengaja bertindak selaku amil zakat melakukan pengumpulan, pendistribusian, atau pendayagunaan zakat tanpa izin pejabat yang berwenang.

UUPZ menegaskan bahwa LAZ yang ingin mendapatkan izin untuk menyalurkan, mendistribusikan dan mendayagunakan zakat setidaknya harus terdaftar sebagai organisasi kemasyarakatan Islam yang mengelola bidang pendidikan, dakwah, dan sosial. Mencermati ketentuan Pasal 41 maka dapat ditafsirkan merupakan suatu tindakan kriminalisasi.

Menurut Direktur Pemberdayaan Zakat Kementerian Agama (Kemenag) RI Rohadi Abdul Fatah, tidak adanya sanksi bagi LAZ yang tidak berijin, menjadi salah satu pemicu tidak efektifnya pengelolaan dana zakat di Tanah Air. Dari data yang dimiliki Kemenag RI, baru sekitar 18 LAZ yang telah mendaftar dan mendapat akreditasi dari Kemenag RI,. padahal saat ini ada sekitar 260 LAZ ( Rohadi Abdul Fatah, www.jumaljakarta.wordpress).

Berdasarkan alasan tersebut, menarik untuk diteliti, bagaimana pandangan ahli hukum Islam mengenai pengelolaan zakat yang dilakukan oleh lembaga pengelola zakat serta kriminalisasi dalam Pasal 41 UUPZ terhadap amil dengan mengkaji ukuran-ukuran untuk sebuah kriminalisasi dari perspektif hukum pidana. 


\section{B. Metode Penelitian}

Penelitian ini merupakan penelitian yuridis empiris, kombinasi antara penelitian hukum normatif dan penelitian hukum empiris. Penelitian ini mengkaji bagaimana pandangan Lembaga Amil Zakat dan para ahli hukum Islam terkait ketentuan bahwa lembaga pengelola zakat harus berijin dari pemerintah, serta mengkaji ketentuan pidana dalam Pasal 41 Undang Undang Nomor 23 Tahun 2011 yang menyangkut pelanggaran terhadap ketentuan tersebut.

Penelitian yang dilakukan meliputi penelitian kepustakaan untuk mendapatkan data sekunder yang berupa UU No. 23 Tahun 2011 dan penelitian lapangan untuk mendapatkan data primer, dengan metode Focus Group Discusion menghadirkan narasumber ahli Hukum Pidana dan ahli Hukum Islam dan responden dari LAZ-LAZ yang sudah maupun belum berijin. Analisis data baik yang diperoleh dari hasil penelitian pustaka maupun Focus Group Discussion dilakukan secara diskriptif kualitatif guna menjawab permasalahan.

\section{PEMBAHASAN}

1. Pandangan Ahli Hukum Islam mengenai pengeolaan zakat oleh lembaga pengelola Zakat

Berdasarkan QS At-Taubah ayat 10, para ulama sepakat, wajib atas penguasa mengangkat para petugas zakat atau amil. Pengelolaan zakat, baik dalam pengumpulan maupun pendistribusian zakat, selama ini dikelola oleh dua lembaga yakni Badan Amil Zakat Nasional (BAZNAS) dibantu Lembaga Amil Zakat (LAZ).

Amil dapat memberikan kemudahan bagi para muzakki untuk menyalurkan zakatnya disertai kepercayaan bahwa zakatnya akan disalurkan dan dipergunakan sesuai ketentuan agama. Bagi mustahik, amil pun dapat memberikan bimbingan sehingga tidak selamanya mereka menjadi mustahik, namun dapat beralih sebagai muzakki.

Semenjak dikeluarkannya UU No. 23 Tahun 2011 tentang Pengeloaan Zakat sebagai pengganti UU No. 38 Tahun 1999 banyak perubahan substansi dari UU tersebut yang mengharuskan masyarakat mengikuti semangat dari UU yang baru. Padahal secara filosofis-sosiologis, adanya suatu UU haruslah mengakomodir semangat yang ada di dalam masyarakat bukan masyarakat yang harus mengikuti isi dari suatu Undang-Undang.

Pokok-pokok pikiran yang tercantum dalam UU Nomor 23 Tahun 2011, dapat dipaparkan sebagai berikut : a. Sentralisasi pengelolaan zakat nasional oleh BAZNAS yang melaksanakan fungsi perencanaan, pelaksanaan, pengendalian, pelaporan dan pertanggungjawaban.

b. Masyarakat dapat mendirikan LAZ untuk membantu BAZNAS

c. LAZ wajib mendapat izin Menag dengan syarat terdaftar sebagai ormas Islam, berbadan hukum, mendapat rekomendasi BAZNAS, berbentuk badan hukum, ada program pendayagunakan zakat, dan bersedia diaudit secara syariah dan keuangan.

Salah satu muatan materi dari diundangkannya UU No. 23 tahun 2011, yang telah mengatur pengelolaan zakat yang terintegrasi oleh pemerintah adalah adanya pembagian kewenangan yang menyangkut siapa yang berhak mengumpulkan, mengelola, dan mendistribusikan zakat. Dua lembaga yang mempunyai kedudukan vertikal tampak terlihat diantara kewenangan BAZNAS dan LAZ. BAZNAS mempunyai kewenangan yang besar karena melakukan pengelolaan zakat secara nasional, berbeda dengan LAZ yang sifatnya membantu pengumpulan, pendistribusian dan pendayagunaan zakat (Pasal 1 angka (7) dan (8) UU No 23 Tahun 2011).

Menurut Alim Mu'allim (disampaikan dalam sarasehan "Mengkritisi UU no 23 Tahun 2011" di UII pada 29 Maret 2012 ), menyatakan bahwa zakat memang harus dikelola oleh lembaga khusus yaitu amil, sebagaimana ketentuan dalam Al Quran. Namun apakah amil harus dibentuk oleh pemerintah ataukah dapat dibentuk oleh masyarkat, tidak ada pengaturan yang mengatur. Ketentuan pengelolaan zakat dalam UU Nomor 23 Tahun 2011, masih ada beberapa hal yang perlu diperbaiki. Pertama, kaitannya dengan penempatan Sumber Daya Manusia. BAZNAS selaku badan yang mengelola zakat secara nasional terdiri dari 11 orang, dengan rincian ada 8 orang unsur masyarakat dan 3 dari unsur pemerintah (Pasal 8 ayat (1) dan (2) UU No 23 Tahun 2011). Idealnya anggota BAZNAS lebih banyak dan penting diisi oleh orang yang sudah berpengalaman dan sudah lama aktif dibidangnya karena berkaitan dengan profesionalisme. Ketentuan yang lain menyebutkan bahwa LAZ sifatnya hanya membantu, dan tidak punya otoritas yang seimbang dengan BAZNAS. Dalam satu sisi sifatnya hanya membantu, tetapi di lain sisi 
LAZ harus menyiapkan laporan akuntan publik, pelaporan dan orang-orangnya harus professional. Kedua, bahwa LAZ dalam UU No. 23 tahun 2011 dapat mempunyai otoritas asal menjadi organisasi masyarakat tertentu yang mempunyai program di bidang pemberdayaan masyarakat, padahal selama ini LAZ bergerak secara independen (tidak menginduk ormas tertentu). Upaya yang ditawarkan di sini menginduk pada ormas, padahal ormas itu belum menjamin independensi. mengingat zakat itu milik semua orang/golongan, sehingga dikhawatirkan kalau harus dalam bentuk ormas akan terjadi pengkotak-kotakan. Misal antara orang yang bukan dari paham Nahdatul Ulama (NU) ingin membayar zakat, kecil kemungkinan dia membayar ke organisasi masyarakat yang dimiliki oleh Muhammadiyah atau kita membuat ormas baru yang benar-benar independen. Karena di DIY sendiri ormas itu sudah ada bahkan banyak. lalu apakah kita menginduk pada ormas yang sudah ada atau mendirikan ormas khusus yang menangani ini. Ketiga, ialah mengenai insentif yang diberikan kepada pengelola zakat yang dinilai masih rendah bila dibandingkan dengan Malaysia yang sudah dapat memberikan insentif besar bagi para pengelola zakat. Tentunya ini menjadi sebuah tantangan baru pasca diberlakukannya UU No 23 tahun 2011.

Selain itu Undang-Undang harus dibuat dalam 2 pandangan, yakni content dan law nya. Content-nya sudah banyak dibahas, yakni apa sebenarnya tujuan dari Undang-Undang tersebut, dalam hal ini beliau mengkritisi masalah seberapa bagusnya bila zakat dikelola oleh organisasi kemasyarakatan. Berbicara law, berbicara siapa yang merumuskan Undang-Undang, apakah melibatkan praktisi, praktisi tidak dilibatkan dalam penyusunan Undang-Undang ini (Undang-Undang Nomor 23 Tahun 2011). Seharusnya dalam penyusunan suatu peraturan dapat melihat konstelasi dan aspirasi yang ada dalam masyarakat. Sehingga peraturan perundangan itu dapat mencerminkan seluruh kepentingan lapisan masyarakat yang dapat dilaksanakan.

Pasal yang menjadi kontroversi adalah pasal 18 ayat (2) yang menyebutkan, bahwa setiap Lembaga Amil Zakat yang ingin mendapatkan izin untuk menyalurkan, mendistribusikan dan mendayagunakan zakat setidaknya harus terdaftar sebagai organisasi kemasyarakatan Islam yang mengelola bidang pendidikan, dakwah, dan sosial. Selain itu, dalam pasal 38 dan pasal 41 menyebutkan bahwa setiap orang yang bertindak sebagai Amil Zakat dilarang untuk mengumpulkan, mendistribusikan dan mendayagunakan Zakat tanpa izin dari pejabat yang berwenang dan apabila melanggar, maka akan di kenakan kurungan 1 tahun dan denda 50 Juta. Sehingga terlihat adanya suatu upaya untuk mengurangi LAZ-LAZ yang sudah ada sebelum UU No. 23 tahun 2011 itu diundangkan, meskipun pemerintah juga menginginkan adanya pola pengelolaan oleh lembaga penyalur zakat yang terintegrasi secara nasional.

Dalam Naskah Akademik RUU PengeIolaan Zakat, dijelaskan bahwa selama berlakunya UUPZ lama, belum ada lembaga yang berwenang melakukan pengawasan terhadap BAZ maupun LAZ, juga belum ada lembaga yang membuat kebijakan operasional untuk BAZ dan LAZ serta terjadinya tumpang tindih penghimpunan dan penyaluran zakat. Hal itu berakibat timbulnya kelemahan pertanggungjawaban terhadap publik, akuntabilitas, tranparansi dan penataan kelembagaan, sehingga pengelolaaan zakat sesuai prinsip good governance belum terwujud (Draft Naskah Akademik UUPZ, Komisi VIII DPR RI, 20 Mei 2010).

Bekti Hendrianto (MUI Yogya) menyatakan bahwa amil memang harus profesional dalam pengelolaan zakat. Permasalahan muncul dikarenakan kewenangan antara BAZ sebagai amil yang mewakili unsur pemerintah dan LAZ yang merupakan amil zakat bentukan masyarakat, yang awalnya berkedudukan sejajar berdasarkan ketentuan UU Nomor 38 Tahun 1999, menjadi vertikal dalam ketentuan UU Nomor 23 Tahun 2011. Jiwa UU pengelolaan zakat yang baru adalah mengintegrasikan seluruh pengelolaan zakat di Indonesia di bawah pemerintah melalui lembaga BAZNAS. Namun, pertanyaannya mengapa demikian. Apakah selama ini LAZ tidak profesional? Apakah pengelolaan zakat yang dilakukan oleh LAZ bentukan masyarakat salah dan bertentangan dengan syariah ? Bekti lebih sepakat bahwa jawaban dari dua pertanyaan tersebut adalah tidak. Selanjutnya, bahwa implementasi UU Pengelolaan Zakat tanpa peraturan pelaksanaan yang hingga saat ini belum ada, jika ini dipaksakan maka akan 
menimbulkan masalah baru. Kaidah yang seharusnya digunakan adalah "hindari mudharat yang tidak jelas harus diutamakan dari pada mengambil manfaat yang belum jelas". Untuk mengukur itu, dari segi implementasi dapat digunakan beberapa tinjauan teori ekonomi regulasi yang menyatakan bahwa regulator dan eksekutor itu haruslah dipisah. Ini semacam trias politika nya ilmu politik. Di UU ini, BAZNAS dilihat dari ilmu regulasi, mempunyai peran ganda yakni sebagai regulator sekaligus eksekutor. Sehingga solusinya harus ada pemisahan yang jelas antara regulator dalam hal ini BAZNAS dan eksekutornya LAZ-LAZ yang memungkinkan mekanisme check and balances akan dapat berjalan. Ditinjau dari sisi realita. kinerja BAZNAS yang akan mengelola sebuah industri/ proyek dengan sebuat aset potensial mencapai 17 triliun pertahun, ditambah dari penggabungan dana yang dikumpulkan LAZLAZ dapat mencapai 89,9 triliun pertahun, adalah permasalahan yang tidak kecil. Masalahnya kemudian apakah BAZNAS akan mampu mengelola itu. Solusinya, UU Nomor 23 Tahun 2011, masih membuka peluang untuk dilakukan Judicial Review (Pengujian Peraturan Perundang-Undangan) ke Mahkamah Konstitusi yang dipelopori oleh berbagai kalangan baik FOZ dan akademisi maupun masyarakat lainnya. Selain itu, yang terpenting adalah spirit bahwa zakat harus dikelola secara professional. Meskipun banyak kebaikan dan kelemahan yang selama ini sudah berjalan (disampaikan Bekti Indrianto, dalam FGD di Fak. Hukum UGM , 28 April 2012).

Menurut peneliti, kinerja penghimpunan dan pendayagunaan dana zakat lebih banyak ditentukan oleh legitimasi dan reputasi lembaga pengumpul zakat, bukan melalui sentralisasi kelembagaan oleh pemerintah. Pasal 28 C ayat (2) UUD 1945, "setiap orang berhak memajukan dirinya dalam memperjuangkan haknya secara kolektif untuk membangun masyarakat, bangsa dan negaranya". Apabila selama ini pengumpulan zakat telah demikian gemilang dikelola oleh Lembaga Amil Zakat dan tidak ada fakta yang menunjukkan adanya penyimpangan dalam pengelolaan zakat oleh Lembaga Amil Zakat, maka apresiasi pemerintah seharusnya tidak ditentukan dalam penetapan Undang Undang yang kurang mencerminkan aspirasi masyarakat.

Apabila mencermati Naskah Akademik RUUPZ oleh Komisi VIII DPR RI tanggal 20
Mei 2010 yang mengharuskan LAZ mempunyai ijin dari pemerintah, dimaksudkan untuk merekonstruksi organisasi pengelola zakat sehingga tercipta koordinasi antar operator zakat, pengelolaan yang professional, peningkatan pendayagunaan zakat untuk mengubah masyarakat menjadi sejahtera serta adanya pengawasan yang efektif dari lembaga yang dibentuk oleh pemerintah.

2. Kriminalisasi Ketentuan Pasal 41 UndangUndang Nomor 23 Tahun 2011 Tentang Pengelolaan Zakat Dilihat Dari Perspektif Hukum Pidana.

Ketentuan dalam pasal 41 UndangUndang Nomor 23 Tahun 2011 tentang Pengelolaan Zakat adalah suatu ketentuan yang mengatur tentang pelarangan bagi setiap orang, baik orang perseorangan maupun badan hukum (Pasal 1 angka 10 UU No 23 Tahun 2011), yang melanggar ketentuan dalam Pasal 38 Undang-Undang tersebut, yakni mengenai pelarangan untuk bertindak sebagai amil zakat yang melakukan pengumpulan, pendistribusian, atau pendayagunaan zakat tanpa izin pejabat yang berwenang. Ketentuan dalam Pasal 41 Undang-Undang Pengelolaan Zakat ini merupakan rumusan ketentuan pasal pidana yang akan mengancam amil yang tidak berijin (Pasal 41 UUPZ).

Menurut Yeni Widowati (FH UMY), dengan adanya ketentuan tersebut akan memunculkan kekhawatiran terhadap pengelola zakat di masjid-masjid yang ada di kampung-kampung akan merasa terkungkung dengan ketentuan dalam pasal 41 Undang-Undang Pengelolaan Zakat (disampaikan dalam FGD di FH UGM, 28 April 2012).

Kebijakan Kriminal adalah suatu usaha yang rasional dari masyarakat dalam menanggulangi kejahatan (Sudarto, 1981: 38). dan upaya penanggulangan kejahatan tersebut merupakan bagian integral dari upaya perlindungan masyarakat untuk mencapai kesejahteraan masyarakat (Barda Nawawi, 2008: 4). Pemberian saknsi terhadap amil seperti yang diatur dalam Pasal 41 tersebut merupakan bentuk kriminalisasi. Menurut pembentuk undang-undang perbuatanperbuatan yang dikriminalisasikan adalah perbuatan yang dianggap suatu perbuatan yang mengarah akan merugikan masyarakat (pendapat Supriyadi dari FH UGM, dalam FGD di FH UGM, 28 april 2012). 
Lebih lanjut Supriyadi menyatakan, Kebijakan Kriminal/ Politik penanggulangan tindak pidana, pada hakikatnya dapat dilakukan dengan dua cara, yaitu:

a. Menggunakan sarana diluar hukum pidana.

Dalam menggunakan sarana diluar hukum pidana, titik tekan yang digunakan adalah suatu pencegahan yakni untuk mencegah agar suatu perbuatan tersebut tidak terjadi. Sehingga langkah dalam sarana ini lebih bersifat preventif.

b. Menggunakan sarana hukum pidana

Dalam menggunakan sarana hukum pidana langkah yang digunakan lebih menitikberatkan pada aspek represif. Penggunaan sarana hukum pidana dalam penangulangan kejahatan yang dilakukan, perlu menggunakan berbagai macam tahapan yakni tahapan formulasi, aplikasi, dan eksekusi. Dalam tahapan yang pertama yakni tahap proses memformulasikan perbuatan-perbuatan yang diancam dan yang akan merugikan dalam peraturan perundang-undangan dan proses kriminalisasi tersebut masuk dalam tahap yang pertama ini.

Dalam menata kehidupan masyarakat, sesungguhnya fungsi hukum bisa diartikan:

a. Hukum sebagai sosial kontrol (social control)

Dalam menerapkan mekanisme kontrol sosial agar masyarakat mematuhi kaidah yang berlaku serta untuk memberi efek jera terhadap pelanggaran yang dilakukan oleh masyarakat, maka pencatuman sanksi pidana dalam rumusan suatu aturan hukum adalah alat yang tepat pada fungsi hukum sebagai alat kontrol sosial.

b. Hukum sebagai alat untuk mengubah masyarakat (law is a tool of social engeneering)

Fungsi hukum sebagai alat untuk mengubah masyarakat, oleh Roscoe Pound yang dikutip Zainuddin Ali, dianalogkan sebagai proses mekanik yang harus dilakukan oleh penyelenggara negara dalam melakukan tugasnya dengan memperhatikan keadaan sosial masyarakat dan nilai-nilai sosial serta hakhak individu. Lebih lanjut, Pound menjelaskan, hukum sebagai social en- gineering berkaitan dengan fungsi dan keberadaan hukum sebagai pengatur dan penggerak perubahan masyarakat, maka hak yang bagaimana yang seharusnya diatur oleh hukum dan hak apa yang dituntut oleh masyarakat. Disini diperlukan kebijaksanaan dari political institution dalam menyelaraskan antara kepentingan umum dan kepentingan pemerintah, bukan dengan pencantuman sanksi negatif bagi pelanggar, sehingga tujuan dari hukum sebagai alat pengubah masyarakat dapat tercapai (Zainuddin Ali, 2005: 22-27)

Mencermati Naskah Akademik RUU Pengelolaan Zakat, Komisi VIII DPR RI, tanggal 20 Mei 2010, yang menguraikan beberapa alasan pembuatan undang-undang zakat yang baru, yaitu pengumpulan zakat yang terjadi selama ini masih tumpang tindih, zakat yang potensi jumlahnya cukup besar namun distribusinya belum merata sehingga belum dapat mewujudkan keadilan, kesejahteraan sosial dan dapat mengurangi angka kemiskinan di Indonesia, maka fungsi hukum lebih tepat sebagai alat pengubah masyarakat. Sehingga pengenaan sanksi bagi LAZ yang belum berijin dalam Pasal 41 UUPZ tidak sesuai dengan tujuan dari law is a tool of social engineering.

Apabila akan mengkritisi krimi-nalisasi yang dilakukan pembentuk undang-undang pada ketentuan dalam pasal 41 sudah tepat ataukah belum, maka setidaknya terdapat dua hal yang perlu diperhatikan, yakni:

a. Segi formulasinya/ dari segi perumusannya Terhadap ketentuan dalam pasal 41 Undang-Undang Pengelolaan Zakat, pendapat dari Supriyadi (dalam FGD FH UGM, 28 Aprl 2012), dari segi formulasinya terdapat dua hal yang perlu diperhatikan, yaitu:

1) Subyek hukum

Bahwa dalam rumusan pasal 41 subyek hukum yang dirumuskan yaitu menggunakan kata setiap orang, dan makna dari kata setiap orang itu sendiri adalah orang perseorangan maupun badan hukum, dimana makna dari ketentuan tersebut sangatlah luas sekali. Sehingga berkaitan dengan makna pertama yaitu orang perseorangan amil yang tersebar di kampungkampung dan makna ke dua adalah 
amil yang berbentuk badan hukum dan hal ini dapat mengakibatkan pengaturan yang tumpang tindih dengan peraturan perundangundangan lain yang mengatur mengenai badan hukum.

2). Perumusan delik

Perumusan delik yang digunakan dalam pasal 41 Undang-Undang Pengelolaan Zakat adalah perumusan delik secara formal, sehingga perbuatan yang dilarang/ delik tersebut adalah lebih menitik beratkan pada perbuatannya yaitu perbuatan yang tanpa ijin. Sebenarnya agar ketentuan dalam pasal 41 agar menjadi lebih baik, sebaiknya ditambahkan ketentuan mengenai akibat dari perbuatan yang dilarang tersebut, sehingga dalam susunan kata dalam pasal 41 ditambahkan kata, "yang merugikan" sehingga perumusan delik yang digunakan menjadi delik materii.

b. Alasan yang mendasar dalam kriminalisasi

Pada dasarnya makna dari ketentuan dalam pasal 41 Undang-Undang Pengelolaan Zakat adalah apakah terdapat alasan yang mendasar bahwa seseorang yang bertindak selaku amil zakat tetapi amil tersebut tidak memilki ijin dari kementerian agama atau pejabat yang ditunjuk, kemudian dapat disamakan dengan seorang kriminal. Sehingga yang menjadi pertanyaan selanjutnya adalah apakah sudah ada alasan yang mendasar atau apakah sudah tepat bila sanksi pidana itu diintensifkan, seperti yang dirumuskan dalam pasal 41 tersebut. Pada dasarnya tidak ada jaminan bahwa pengelolaan yang ditangani oleh badan hukum atau lembaga yang telah berijin akan lebih baik dengan amil zakat yang tidak berbentuk badan hukum atau tidak berijin, karena hal tersebut tergantung dari pengelolaanya, penyelewengan atas pengelolaan zakat bisa saja terjadi. Selain itu pada hakikatnya apabila berkaitan dengan keuangan negara, hal tersebut bisa dibawa ke dalam ranah korupsi, tetapi bila itu memang yang diselewengkan dana dari Muzakki, bisa dikenakan ketentuan dalam pasal yang mengatur tentang penggelapan, yakni penggelapan uang Muzakki.

Terkait dengan kriminalisasi dalam pasal 41 Undang-Undang Pengelolaan Zakat. Pada dasarnya dalam proses kriminalisasi suatu perbuatan menjadi perbutaan pidana terdapat berbagai kriteria atau parameter yang dapat digunakan dalam mengkriminalisasikan suatu perbuatan baik seperti yang telah dikemukakan oleh Sudarto, Muladi, Bassiouni, maupun yang disampaikan dalam hasil Simposium Pembaharuan Hukum Pudana Nasional pada bulan Agustus 1980 di Semarang. Kriteria/ parameter tersebut dapat digunakan untuk menguji apakah pasal 41 sudah tepat ataukah belum. Lebih lanjut Supriyadi menyatakan, dalam kriteria/ parameter tersebut terdapat pokok-pokok pikiran bila pembentuk undangundang akan mengkriminalisasi suatu perbuatan, yang antara lain adalah:

a. Memperhatikan tujuan hukum pidana

Bahwa Penggunaan hukum pidana harus memperhatikan tujuan pembangunan nasional, yaitu mewujudkan masyarakat adil dan makmur yang merata baik materiil maupun spiritual berdasarkan pancasila. Sehubungan dengan ini maka penggunaan hukum pidana bertujuan untuk menanggulangi kejahatan dan mengadakan pengugeran terhadap tindakan penanggulangan itu sendiri, demi kesejahteraan dan pengayoman masyarakat. Dalam faktanya di lapangan, sebelum dan sesudah diundangkannya Undang-Undang Nomor 23 tahun 2011, sudah terdapat lembaga-lembaga nonprofit yang telah mengelola zakat dengan ikhlas. Sehingga, kriminalisasi dalam pasal 41 untuk perbuatan yang dilakukan oleh amil sebagaimana yang terdapat dalam Pasal 38 Undang-Undang Pengelolaan Zakat dirasa kurang sesuai dengan tujuan hukum pidana yaitu untuk menanggulangi kejahatan demi terwujudnya kesejahteraan masyarakat

b. Terdapat unsur victimizing (Korban)

Selanjutnya Yeni Widowati (FGD di FH UGM, 20 April 2012) menyatakan, bahwa perbuatan yang diusahakan untuk dicegah dan ditanggulangi dengan hukum pidana harus merupakan perbuatan yang tidak dikehendaki, yaitu perbuatan yang

Kriminalisasi Pengelolaan Zakat... 52 
mendatangkan kerugian baik materiil dan/ atau spritual atas warga masyarakat atau akan mendatangkan korban, walaupun tidak semua perbuatan yang mendatangkan korban harus diklasifikasikan sebagai perbuatan yang dilarang dan diberi sanksi pidana atau dikriminalisasikan. Ketentuan kriminalisasi dalam pasal 41 UUPZ adalah ketentuan mengenai dipidananya seseorang baik orang perseorangan maupun badan hukum yang bertindak sebagai amil zakat tanpa ijin pejabat yang berwenang.

Menurut Supriyadi (FGD FH UGM, 28 april 2012) pada dasarnya tidak ada korelasi antara bertindak sebagai amil zakat tanpa ijin yang berwenang dengan akan mendatangkan kerugian atau korban karena bagaimana bila hasilnya tetap sampai pada mustahiq, apakah akan ada yang dirugikan. Selain itu yang perlu mendapatkan perhatian adalah masalah penyelewengan pengelolaan dana zakat, karena penyelewengan tersebut tidaklah berkaitan dengan suatu ijin, akan tetapi bila seseorang baik orang perseorangan maupun badan hukum yang bertindak sebagai amil zakat belum memiliki ijin tetapi dalam pengelolaan zakatnya dilakukan sesuai dengan tuntutan agama dan zakatnya sampai pada mustahiq, serta tidak merugikan Muzakki, maka perbuatan tersebut tidak akan mendatangkan kerugian. Yeni Widowati menambahkan, terkait dengan penyelewengan pengelolaan zakat tersebut, bila subyek hukum yang melakukan penyelewengan adalah pegawai negeri dan penyelenggara negara, dimana pegawai negeri itu tidak hanya pegawai negeri sipil tetapi juga termasuk diantaranya suatu lembaga yang menggunakan dana dari negara (APBN), maka apabila penyelewengan pengelolaan zakat tersebut akan merugikan masyarakat, sudah dapat dikenakan ketentuan dalam Undang-Undang Tindak Pidana Korupsi.

Pada hakikatnya, indikator yang dapat digunakan dalam mengukur ketentuan dalam pasal 41 tersebut akan mendatangkan kerugian atau tidak adalah pada pengelolaannya, yakni pengelolaan yang sudah sesuai dengan tuntunan agama bukan pada pengelolaan yang tanpa ijin. Sehingga tidak ada korelasi antara unsur akan mendatangkan korban atau kerugian dengan pengelolaan pengumpulan, pendistribusian dan pendayagunaan zakat yang tanpa ijin karena indikator tersebut dapat dinilai dari pengelolaannya itu sendiri.

c. Harus memperhitungkan prinsip biaya dan hasil (cost and benefit principle)

Bahwa dalam penggunaan hukum pidana haruslah memperhatikan biaya dan hasil. Biaya yang dikeluarkan harus sesuai dengan harapan yang akan dicapai, selain itu juga harus mempertimbangkan akibat dari suatu perbuatan pidana, yaitu efektifitasnya dan jangan sampai akan berdampak kriminogen lebih lanjut. Undang-undang tersebut diundangkan pada tanggal 25 Nopember 2011, cost atau biaya yang digunakan untuk membuat undang-undang dimulai dari menyusun rancangan, sosialisasi, pembicaraan di parlemen namun ternyata setelah undang-undang tersebut diundangkan hanya ditujukan untuk sekelompok atau sebagian orang yang sebelumnya telah mengelola zakat dengan ikhlas sehingga dikhawatirkan akan menimbulkan ketidaknyamanan dalam melakukan pengelolaan zakat (pendapat Yeni Widowati dalam FGD di FH UGM, 28 April 2012).

Dalam FGD tsb Supriyadi menambahkan bahwa manfaat dari UndangUndang tersebut belum terlihat, karena faktanya walaupun dengan diundangkannya Undang-Undang Pengelolaan Zakat amil zakat yang belum berijin tidak terdorong untuk mengurus ijin yang dipersyaratkan oleh undang-undang. Dalam Undang-Undang Pengelolaan Zakat memberikan waktu transisi 5 tahun sehingga ketentuan dalam pasal 41 Undang-Undang Pengelolaan Zakat, akan dapat dilaksanakan pada tahun 2016 bagi amil zakat yang belum memenuhi ketentuan undang-undang tersebut karena dalam ketentuan transisi/ peralihan adalah "wajib menyesuaikan".

d.Harus memperhatikan kapasitas atau kemampuan daya kerja dari badanbadan penegak hukum (tidak overbelasting).

Selain beberapa persyaratan diatas, menurut Supriyadi (FGD, FH UGM, 28 April 2012) bahwa dalam penggunaan hukum pidana harus memperhatikan 
kemampuan daya kerja aparat penegak hukum, jangan sampai ada kelebihan beban tugas sehingga mengakibatkan dampak yang kurang baik terhadap peraturan itu sendiri.

Berkaitan dengan pengekan hukumnya, pihak kepolisian sebagai aparat penegak hukum terdepan dan berkaitan dengan pelanggaran yang diatur dalam pasal 41 Undang-Undang Pengelolaan Zakat penyidikan atas pelangaran yang terjadi dilakukan oleh polisi, karena dalam ketentuan tersebut tidak disebutkan penyidik lain, apakah nantinya setelah masa transisi 5 tahun tersebut, akan benar-benar melakukan penegakan apabila ketentuan dalam pasal 41 tersebut dilanggar. Selain itu permasalahan yang timbul lainnya adalah apakah saat ini polisi juga sudah mengetahui dengan adanya ketentuan pasal 41 Undang-Undang Pengelolaan Zakat tersebut, saat ini aparat penegak hukum khususnya kepolisian sudah disibukkan dengan perkara pembunuhan, pemerkosaan, terorisme dan sebagainya, dan setalah berlakunya ketentuan dalam pasal 41 Undang-Undang Pengelolaan Zakat pihak kepolisian memiliki tugas baru yaitu ikut mengurus masalah pengelolaan zakat. Sehingga hal tersebut akan mengakibatkan overbelasting yaitu terjadi kelebihan beban aparan penegak hukum karena faktanya jumlah aparat penegak hukum tidak sesuai dengan jumlah beban tugas yang harus dilaksanakan, dan ini bisa menambah beban bagi kepolisian

d. Adanya Public support dari masyarakat

Berkaitan dengan public support dari masyarakat, bahwa ketika pembentuk undang-undang akan mengkriminalisasikan suatu perbutan harusnya mendapatkan dukungan publik dari orangorang/ masyarakat yang akan terkena dampak pasal 41 Undang-Undang Pengelolaan Zakat. Dalam perumusan Undang-Undang Pengelolaan Zakat khususnya pasal 41, apakah pandangan masyarakat merasa bahwa perbuatan seseorang yang bertindak sebagai amil zakat tanpa ijin dari pejabat yang berwenang masih dirasa bukan perbuatan yang tercela dalam masyarakat, dan perbuatan tercela dalam pandangan masyarakat adalah apabila pengelolaan zakat tidak dilaksanakan dengan sebenarnya atau terjadi penyelewengan atau penggelapan oleh amil sehingga merugikan muzzaki dan mustahiq (pendapat Supriyadi, FGD di FH UGM, 28 April 2012). Sehingga pada dasarnya perumusan dalam pasal 41 UndangUndang Pengelolaan Zakat diklasifikasikan sebagai suatu perbuatan yang terlarang dan diberikan sanksi pidana kurang mendapat dukungan dari masyarakat, karena pada hakikatnya perbuatan seseorang dengan bertindak sebagai amil zakat tanpa ijin dari pejabat yang berwenang masih dirasa bukan perbuatan yang tercela dalam masyarakat.

Apabila mencermati beberapa ukuran kriminalisasi di atas, maka kriminalisasi pada pasal 41 masih kurang mendasar dan terlalu berlebihan, karena berkaitan dengan unsur tujuan hukum pidana, victimizing, cost and benefit principle, public support, law enforceble-nya masih perlu dipertanyakan dan bila kita merujuk pada ketentuan dalam hukum Islam adalah seharusnya yang diberikan sanksi adalah bagi Muzakki yang tidak membayarkan atau menunaikan zakatnya bukan pada amil zakat yang melakukan pengumpulan, pendistribusian, atau pendayagunaan zakat tanpa izin pejabat yang berwenang. Menurut kacamata hukum pidana, tidak ada satu pun kriteria/ parameter yang digunakan dalam mengkriminalisasi suatu perbuatan terpenuhi dalam mengkriminalisasi pasal 41 Undang-Undang Pengelolaan Zakat sehingga apabila ketentuan dalam pasal 41 Undang-Undang Pengelolaan Zakat dipaksakan berlaku, dikhawatirkan akan menambah tugas/ beban penegak hukum dan selain itu urusan zakat ini adalah urusan agama yakni urusan Ibadah.

Sehingga ketentuan dalam pasal 41 tersebut, sebaiknya dilakukan judicial review sebelum tahun 2016, karena ketentuan dalam Undang-Undang tersebut adalah "wajib menyesuaikan" selama 5 tahun, dan bila tidak menyesuaikan secara formal amil yang tidak berijin bisa dikenakan ketentuan dalam pasal 41 tersebut. 


\section{Simpulan}

1. Ahli Hukum Islam menyatakan bahwa para ulama sepakat, wajib atas penguasa untuk mengangkat amil atau lembaga pengelola zakat. Namun rumusan pengelolaan $\mathrm{z}$ a $\mathrm{k}$ a $\mathrm{t}$ secara sentralisasi berada di tangan pemerintah, masih dapat diperdebatkan dengan melihat peran masyarakat yang gemilang dalam pengelolaan zakat melalui LAZ.

2. Kriteria kriminalisasi yang meliputi pemidanaan harus memperhatikan tujuannya, adanya unsur victimizing, prinsip biaya dan hasil, dan dukungan masyarakat, tidak terpenuhi dalam mengkriminalisasi LAZ seperti yang ditentukan dalam Pasal 41 UU Pengelolaan Zakat. Maksud dari pemerintah membentuk UUPZ baru, adalah untuk lebih meningkatkan pengumpulan, pendistribusian dan pendayagunaan zakat, sehingga dapat menciptakan masyarakat Indonesia yang sejahtera. Mencermati maksud tersebut, dirasakan kurang tepat ketentuan pemidanaan bagi LAZ karena tidak adanya catatan buruk kinerja LAZ dan apabila hukum dipandang sebagai alat untuk melakukan perubahan sosial, yaitu mengubah masyarakat yang miskin menjadi sejahtera, maka selayaknya bukan pendekatan sanksi yang dilakukan melainkan dengan pemberian insentif. 


\section{Daftar Pustaka}

Barda Nawawi Arief. 2008. Bunga Rampai Kebijakan Hukum Pidana, Perkembangan Penyusunan Konsep KUHP Baru. Jakarta: Kencana Prenada Media Group.

2005. Beberapa Aspek Kebijakan Penegakan dan Pengembangan Hukum Pidana. Bandung : Citra Aditya Bakti.

M. Yusuf Qardhawi. 1982. Problema Kemiskinan dan Apa Konsep Islam, diterjemahkan oleh Umar Fanany. Surabaya : Bina IImu.

Muhammad Daud Ali. 1998. Sistem Ekonomi Zakat dan Wakaf. Jakarta : UI Press, Prasetyo, Menyambut UU Zakat Baru, diakses dalam http://www.dsniamanah.or.id

Rohadi Abdul Patah menyampaikan kepada Jurnal Jakarta pada tanggal 30 Oktober 2011 diakses dalam www.jurnaljakarta.wordpress

Sudarto. 1981. Kapita Selekta hukum Pidana. Bandung: Alumni

Zainuddin Ali. 2005. Sosiologi Hukum. Jakarta : Sinar Grafika.

Undang Undang Nomor 23 Tahun 2011 tentang Pengelolaan Zakat, Lembaran Negara Republik Indonesia Tahun 2011 Nomor 115

Undang-Undang Nomor 38 Tahun 1999 tentang Pengelolaan Zakat

Draft Naskah Akademik Rancangan Undang-Undang Pengelolaan Zakat, Komisi VIII DPR RI, Tanggal 20 Mei 2010 